\title{
ESENSI AKUNTANSI LINGKUNGAN DALAM KEBERLANJUTAN PERUSAHAAN
}

\author{
Idrawahyuni $^{* 1}$, Alimuddin ${ }^{2}$, Hamid Habbe ${ }^{3}$, Mediaty ${ }^{4}$ \\ ${ }^{1}$ Jurusan Akuntansi, Fakultas Ekonomi dan Bisnis Universitas Muhammadiyah Makassar, Indonesia \\ ${ }^{2,3,4}$ Departemen Akuntansi, Fakultas Ekonomi dan Bisnis Universitas Hasanuddin, Indonesia \\ *e-mail: idrawahyuni@unismuh.ac.id
}

\begin{abstract}
ABSTRAK
Dalam rangka pencapaian laba, perusahaan sebagai salah satu entitas terkadang mengorbankan aspek sosial dan lingkungannya. Dimana dampak tanggung jawab sosial dan lingkungan dari kegiatan operasi perusahaan tidak terbatas pada investor, yaitu memberikan pengembalian yang maksimal kepada investor. Kepentingan publik dan lingkungan juga perlu mendapat perhatian perusahaan sebagai dukungan atas operasi perusahaan. Pelestarian lingkungan di samping bermanfaat bagi masyarakat di sekitar juga bermanfaat bagi perusahaan khususnya perusahaan yang memanfaatkan lingkungan dan mendapatkan keuntungan dari lingkungannya. Urgensi akuntansi lingkungan sebagai bentuk tanggung jawab perusahaan dalam pengelolaan lingkungan adalah sebagai suatu sistem informasi akuntansi yang menyediakan informasi mengenai aspek lingkungan. Hal ini dimaksudkan agar pihak manajemen dapat meningkatkan kinerja lingkungan sekaligus kinerja keuangannya yang secara tidak langsung akan berdampak pada keberlanjutan perusahaan di masa yang akan datang.
\end{abstract}

Kata Kunci: Akuntansi Lingkungan, Keberlanjutan, Perusahaan, Manajemen

\begin{abstract}
In order to achieve profit, the company as an entity sometimes sacrifices its social and environmental aspects. Where the impact of social and environmental responsibility of the company's operations is not limited to investors, namely providing maximum returns to investors. Public and environmental interests also need company attention as support for the company's operations. Besides preserving the environment, it also benefits the surrounding community and also benefits companies, especially companies that utilize the environment and benefit from the environment. The urgency of environmental accounting as a form of corporate responsibility in environmental management is as an accounting information system that provides information on environmental aspects. This is intended so that the management can improve environmental performance as well as financial performance which will indirectly have an impact on the company's sustainability in the future.
\end{abstract}

Keywords: Environmental Accounting, Sustainability, Company, Management 


\section{PENDAHULUAN}

Aktivitas perusahaan berhubungan dengan beberapa aspek. Dari sudut pandang ekonomi, perusahaan harus memberikan keuntungan secara langsung kepada masyarakat sekitarnya. Dari sisi perusahaan, Ralph mengemukakan bahwa adanya tekanan perusahaan untuk mencari keuntungan sehingga aspek lain yang terlupakan seperti aspek sosial. Orang-orang baik di perusahaan, orang-orang pintar, orang-orang ahli seakan kehilangan semua kemampuan, kebaikan, kejujuran, dan keahliannya dibawah tekanan pemilik modal yang menginginkan keuntungan sebesar-besarnya. Malah yang terjadi sebaliknya, dimana orangorang pintar berusaha melegitimasi tindakan-tindakan tidak terpuji dengan kepintarannya berargumentasi.

Keinginan untuk mendapatkan profit yang maksimal sudah menjadi tyranny yang membuat orang pintar tak berdaya, sehingga membuat orang baik akan bertindak buruk. Tentunya perusahaan bisa melihat banyak contoh dari tyranny memberikan dampak signifikan yang merusak akal sehat manusia. Yang mana kontribusi perusahaan dianggap sebagai entitas yang akan memberikan banyak keuntungan kepada masyarakat, namun ternyata jauh dari anggapan tersebut.

Perubahan cara pandang tata kelola perusahaan dari orientasi pemangku kepentingan pemangku kepentingan sangatlah penting. Pasalnya kehadiran masyarakat memiliki pengaruh aspek sosiologis yang sangat positif baik internal dan eksternal. Pengaruh eksternal memberi kontribusi yang positif pada kemakmuran lebih lanjut membantu dalam pengembangan pekerjaan, meningkatkan produk domestik bruto, meningkatkan pendapatan dan bentukbentuk yang serupa. Sebaiknya, eksternalitas negatif mendorong inefisiensi yang kompetitif seperti: polusi, radiasi, kebisingan, ketidaksetaraan sosial, dan bentuk penggunaan sumber daya lainnya. Menurut Heard dan Bolce (1998) berpendapat bahwa dampak eksternal yang parah adalah polusi udara, kebisingan, kemacetan, polutan, uap air, asam, radiasi, limbah darurat, dan kontaminan serius lainnya [1].

Perusahaan dan lingkungannya harus saling menguntungkan [2]. Sebaliknya, adanya ketimpangan seperti perselisihan antara PT Freeport Indonesia dengan masyarakat papua. Penggunaan lahan adat, adanya kerusakan lingkungan dan kehancuran ekonomi dan sosial adalah fenomena yang serius yang harus diterima masyarakat Papua [3].

Selain itu, peristiwa Chernobyl (1986), konflik Brent Spar (1995) antara Shell dengan Greenpeace, konflik masyarakat lokal Delta Niger dengan pemerintah Nigeria dan Shell yang disertai dengan eksekusi tokoh lokal, Ken Saro Wiwa (1995), dan lainnya sebagai bagian 
kisah nyata betapa motif keuntungan ekonomi semata mampu merusak tatanan sosial dan lingkungan. Termasuk tragedi semburan lumpur panas Porong, Sidoarjo (2006-sekarang), dan masih banyak lagi.

Berkurangnya tanggung jawab perusahaan akan berdampak pada keadaan sosial dan lingkungan masyarakat seperti munculnya kepedulian akan kesadaran masyarakat untuk senantiasa menjaga kelestarian lingkungan sekitarnya. Penelitian Berglund et al. (2012) menunjukkan bahwa ketika kegiatan operasional perusahaan mampu dikelola dengan baik, maka kepercayaan stakeholder akan meningkat sehingga nilai jual perusahaan akan tercipta dengan sendirinya perusahaan [4].

Pada era tahun 1990 hingga 2010-an kepedulian perusahaan global terhadap pelaksanaan tanggungjawab sosial dan pengungkapan informasinya dalam media laporan bisnis atau laporan tahunan, pelaporan berkelanjutan, atau pelaporan tanggung jawab sosial terus meningkat pesat. Tingginya peningkatan kepedulian terhadap pelaksanaan dan pengungkapan informasi tanggung jawab sosial perusahaan di Indonesia bisa di lihat dalam laporan tahunan dan laporan keberlanjutan yang juga semakin pesat [5].

Berlakunya Undang-undang Nomor 40 Tahun 2007 tentang Perseroan Terbatas pasal 74 ayat (1) ini sebagai bentuk perhatian pemerintah. Undang-undang tersebut sebagai bentuk penguatan ketika minimnya entitas bisnis yang memberikan tanggung jawab sosial dan lingkungannya, maka akan mengancam keberlanjutan perusahaannya. Selain itu, adanya peraturan lain yang senantiasa merangsang entitas bisnis untuk ikut serta dalam menjaga dan melestarikan lingkungan dan sosial dimana perusahaan tersebut beroperasi.

Tanggung jawab perusahaan tidak hanya terletak investor atau kepada kreditor, tetapi juga kepada pemangku kepentingan lainnya. Maka dari itu, entitas bisnis tidak hanya memperhatikan kepentingannya, tetapi juga dampak dari kegiatan operasionalnya terhadap lingkungan dalam memaksimalkan keuntungannya. Jika sebuah perusahaan terus beroperasi, maka selama itu pula akan berdampak pada lingkungannya. Berdasarkan uraian diatas, maka yang menjadi masalah dalam penelitian ini yaitu bagaimana kedudukan akuntansi lingkungan dalam keberlanjutan perusahaan?

\section{METODE PENELITIAN}

Penelitian ini menggunakan pendekatan deskriptif dan jenis penelitian yang digunakan adalah studi literatur. Studi literatur yaitu mengumpulkan penelitian-penelitian terdahulu yang berkaitan dengan objek penelitian dengan mengumpulkan data yang bersifat kepustakaan. 
Kemudian melakukan telaah dari hasil penelitian-penelitian yang telah dikumpulkan sesuai dengan masalah yang relevan.

\section{LITERATURE REVIEW}

\section{Akuntansi Lingkungan}

Konsep akuntansi lingkungan muncul sejak tahun 1970-an yaitu di negara Eropa. Salah satu harapan dengan munculnya akuntansi lingkungan adalah peningkatan efisiensi pengelolaan lingkungan dengan melakukan penilaian kinerja kegiatan lingkungan perusahaan. Munculnya akuntansi lingkungan salah satu tujuan yang ingin dicapai adalah untuk meningkatkan efisiensi pengelolaan lingkungan dengan mengevaluasi kegiatan lingkungan perusahaan. Menurut Bell dan Lehman (1999) bahwa "Green accounting is one of the support the green movement in the company or organization by recognizing, quantifying, measuring and disclosing the contribution of the environment to the business process" [6]. Definisi ini menjelaskan bahwa akuntansi lingkungan mencakup unsur-unsur mengidentifikasi, mengukur, mengevaluasi, dan mengungkapkan biaya yang berkaitan dengan operasional lingkungan perusahaan [7].

Akuntansi lingkungan digunakan untuk mengidentifikasi, mengalokasikan, dan menganalisis bahan dan hubungannya dengan arus kas melalui sistem akuntansi lingkungan untuk mengurangi dampak lingkungan dan meningkatkan kinerja keuangan. Definisi lain dari akuntansi lingkungan adalah pengumpulan, analisis, dan penggunaan informasi keuangan upaya peningkatan kinerja lingkungan dan kinerja ekonomi, menuju perusahaan yang tetap eksis di masa mendatang [8].

Beberapa pendapat diatas, maka dapat disimpulkan bahwa akuntansi lingkungan merupakan suatu sistem informasi akuntansi yang menyediakan informasi mengenai aspek lingkungan agar manajemen dapat meningkatkan kinerja lingkungan sekaligus kinerja keuangannya. Dengan mengimplementasikan akuntansi lingkungan dalam suatu entitas bisnis, maka diharapkan lingkungan bisa mempertahankan kelestariannya, karena dengan adanya akuntansi lingkungan maka entitas bisnis akan secara sukarela mematuhi aturan pemerintah dimana perusahaan tersebut berada [9], [10].

\section{Urgensi Akuntansi Lingkungan}

Eksistensi akuntansi lingkungan sesuai perkembangan masa itu bebas nilai. Terkadang ada perubahan yang membutuhkan pengembangan praktik akuntansi dalam menghasilkan unit 
bisnis yang baik. Ketika perusahaan mulai memperhatikan lingkungannya, maka sistem akuntansi pun juga semakin baik. Hal ini meyakinkan perusahaan untuk siap menerima berbagai pengaruh eksternal.

Teori legitimasi dan teori stakeholder adalah teori yang mendukung adanya penerapan akuntansi lingkungan. Teori legitimasi menyatakan bahwa suatu entitas bisnis akan menjamin kegiatan operasionalnya dengan batasan nilai dan aturan yang berlaku dalam wilayah perusahaan tersebut berada. Tujuan pengungkapan perusahaan adalah untuk mendorong perusahaan menjadi ramah lingkungan dan untuk memastikan bahwa prinsip-prinsip pemangku kepentingan dipertimbangkan oleh semua pemangku kepentingan di perusahaan [11]. Entitas bisnis yang berpartisipasi mempunyai persyaratannya sendiri. Manajemen akan berupaya membimbing dan mewujudkan mitra potensial dengan menyediakan kegiatan lingkungan dan sosial. Teori stakeholder menyatakan bahwa perusahaan bekerja tidak hanya untuk keuntungan mereka sendiri, tetapi juga untuk keuntungan mitra mereka.

Mitra perusahaan atau para stakeholder memiliki ekspektasi yang tinggi terhadap bisnis. Manajemen akan berusaha untuk mengatur dan menyelaraskan kebutuhan mitra dalam pelaksanaan lingkungan dan sosial. Dalam teori stakeholder juga menyatakan bahwa perusahaan bukan entitas yang hanya operasional untuk keuntungannya, melainkan memiliki manfaat bagi pemangku kepentingannya.

\section{Hubungan Perusahaan Dengan Stakeholder}

Keinginan untuk meningkatkan kualitas hidupnya dari waktu ke waktu mendorong manusia untuk menciptakan berbagai macam barang dan jasa sebagai pemuasnya. Sebagian barang dan jasa dapat dibuat sendiri, namun sebagian besar lainnya membutuhkan bantuan pihak lain. Perusahaan adalah suatu lembaga yang menjadi produsen barang dan jasa. Aktivitas perusahaan menghasilkan barang dan jasa tersebut seringkali berimplikasi terhadap lingkungan sekitarnya. Dan pada akhirnya yang merasakan dampak negatif dari lingkungan tersebut adalah manusia juga.

Jika ditanyakan secara jujur, perusahaan akan menjawab bahwa mereka tidak berniat untuk merusak lingkungan sekitar perusahaannya. Dimana tujuan utama perusahaan adalah tujuan ekonomi untuk memaksimalkan laba. Namun, dalam rangka untuk memaksimalkan laba itulah, perusahaan kadang-kadang melakukan tindakan yang merusak lingkungan. Dalam artian bahwa perusahaan mengorbankan aspek lingkungan demi aspek ekonomi. 
Masyarakat meyakini bahwa perusahaan yang menyebabkan kerusakan lingkungan, sehingga selain memikirkan keuntungan ekonomi, masyarakat juga membutuhkan perusahaan yang bertanggung jawab dalam perbaikan lingkungan [12]. Paradigma lama di mana perusahaan sebagai entitas bisnis hanya mengejar keuntungan ekonomi atau profit sudah mulai ditinggalkan dan digantikan dengan paradigma modern yaitu triple bottom line dimana keharusan perusahaan untuk selalu mampu adanya keseimbangan antara profit, planet, dan people untuk keberlanjutan perusahaan dalam menghadapi persaingan. Beberapa tahun terakhir, terdapat tekanan kepada perusahaan untuk bertanggung jawab secara sosial, seperti meningkatkan tanggung jawab sosial dan lingkungan, termasuk tanggung jawab karyawan, masyarakat, lingkungan dan lainnya semakin meningkat [13].

Perusahaan sebagai bagian dari entitas sistem sosial dalam kehidupan masyarakat secara keseluruhan, dimana dalamnya tercipta hubungan timbal balik antara perusahaan dan masyarakat. Adanya hubungan timbal balik tersebut, maka dibutuhkan keseimbangan antara kebutuhan untuk perusahaan itu sendiri maupun kebutuhan stakeholder-nya, bukan hanya mengejar profit saja.

\section{Kedudukan Akuntansi Lingkungan Sebagai Bagian dari Tanggung Jawab Perusahaan}

Akuntansi lingkungan bukanlah bidang yang baru, namun merupakan perluasan atau pengembangan dari akuntansi. Dimana peran dan fungsi akuntansi sebagai suatu sistem informasi yang tidak berubah. Secara internal, akuntansi lingkungan digunakan sebagai alat untuk mempersiapkan kebutuhan manajemen informasi perusahaan untuk manajemen lingkungan. Secara eksternal, perlindungan lingkungan digunakan sebagai sarana komunikasi dengan publik, pemberian informasi sebagai bentuk tanggung jawab perusahaan.

Pengelolaan lingkungan untuk meningkatkan kinerja lingkungan membutuhkan informasi-informasi yang dibutuhkan adalah informasi yang lengkap yang meliputi aspek fisik dan aspek ekonomi. Di sinilah peran akuntansi lingkungan yaitu sebagai suatu sistem informasi akuntansi yang bisa menghasilkan informasi lingkungan. Isu lingkungan sangat terintegrasi ke dalam akuntansi [14]. Sejalan dengan Selg (1994) bahwa salah satu langkah yang digunakan dalam melindungi lingkungan di masa depan adalah dengan mengintegrasikan aspek lingkungan ke dalam sistem akuntansi suatu perusahaan [9].

Akuntansi lingkungan atau environmental accounting adalah proses menentukan, mendistribusikan dan menganalisis aliran dan hubungannya dengan aliran dana dengan menggunakan sistem akuntansi lingkungan yang mengurangi dampaknya terhadap 
lingkungan dan meningkatkan kinerja keuangan. Selanjutnya Bennet dan James (1998) mendefinisikan akuntansi lingkungan sebagai proses pengumpulan, analisis dan penggunaan informasi ekonomi dan non ekonomi dalam mengupayakan peningkatan kinerja lingkungan dan ekonomi diharapkan dapat berkelanjutan dalam kurang waktu jangka panjang [8].

Beberapa tahun terakhir ini, krisis ekologi global maupun nasional yang disebabkan kerusakan lingkungan karena diakibatkan oleh adanya eksploitasi sumber daya alam dan lingkungan yang tidak terkontrol. Hal ini menyebabkan dan semakin menimbulkan kekhawatiran, seperti terjadinya bencana alam dan mengancam keberlangsungan kehidupan manusia. Eksploitasi sumber daya alam dan lingkungan yang dilakukan manusia secara umum bertujuan untuk memajukan taraf hidup ekonomi dan meningkatkan kesejahteraan sosial, serta mendorong kemajuan dan kemakmuran rakyat. Namun sebenarnya krisis ekologi tersebut disebabkan oleh hasrat pemerintah dan pelaku ekonomi untuk meningkatkan pertumbuhan ekonomi dan meraup laba yang sebesar-besarnya. Pemerintah dan pelaku ekonomi menghalalkan segala cara, baik yang etis maupun tidak etis, demi mewujudkan hasrat dan kepentingan ekonomi [15].

Pembangunan ekonomi dan bisnis yang dipicu oleh suatu hasrat untuk meningkatkan pertumbuhan ekonomi dengan krisis ekologi dan krisis sosial. Dalam rangka pembangunan ekonomi dan bisnis suatu negara memerlukan empat faktor produksi, yaitu modal, sumber daya alam, teknologi, dan tenaga kerja. Empat faktor produksi tersebut digunakan untuk menaklukan dan menggunakan sumber daya alam dan lingkungan, serta sumber daya ekonomi sosial-masyarakat sesuai dengan perundang-undangan yang berlaku.

Timbulnya keserakahan dari pelaku pasar terhadap masyarakat dan lingkungan demi mendapatkan keuntungan yang sebesar-besarnya dan bisa mendorong pertumbuhan ekonomi yang tinggi terjadi karena adanya kegagalan sistem pasar dalam mengatur perilaku pelaku pasar dan ini bagian dari regulasi yang tidak efektif dan efisien. Dampak dari keserakahan dari pelaku pasar tersebutlah yang menimbulkan krisis ekologi (kerusakan lingkungan, pencemaran lingkungan dan polusi yang tak terkendali, pemanasan global, perubahan iklim, efek gas rumah kaca, degradasi lingkungan, dan sebagainya) dan krisis sosial (meningkatnya jumlah masyarakat miskin, kesenjangan sosial, pengungsian dan penderitaan rakyat yang semakin parah). Krisis sosial dan lingkungan juga akan berdampak pada peningkatan pendapatan dan pertumbuhan ekonomi perusahaan dalam kurun waktu jangka panjang.

Menurut Lako (2016) bahwa terjadinya krisis ekologi di Indonesia disebabkan oleh beberapa faktor pemicu yaitu: a) pusat perhatian ekonomi pembangunan nasional lebih 
menitikberatkan pada aspek-aspek kepentingan ekonomi dan bisnis dengan orientasi utama pada pertumbuhan ekonomi dan laba jangka pendek, b) kegagalan sistemik dan manajemen tata kelola pembangunan ekonomi, bisnis, dan perusahaan yang etis dan kewajiban terhadap masyarakat dan lingkungan, yang mana selama ini sistem dan tata kelola pembangunan ekonomi dan bisnis nasional memberikan keleluasaan kepada para pelaku ekonomi dan bisnis untuk mengeksploitasi sumber daya alam dan lingkungan serta sumber daya sosial-ekonomi masyarakat, c) kegagalan dalam sistem dan tata kelola keuangan perusahaan yang tidak memperhatikan hak-hak dari lingkungan perusahaan berada, dimana selama ini keuangan perusahaan juga dikritik cenderung tidak ramah lingkungan karena mengabaikan faktorfaktor sumber daya alam dan lingkungan, dan d) gagalnya sistem dan praktik akuntansi dalam mengakui, mengukur nilai, mencatat, meringkas, dan melaporkan informasi akuntansi yang berkaitan dengan objek, peristiwa dan kejadian atau transaksi sosial dan lingkungan merupakan satu kesatuan dengan informasi keuangan, dimana yang selama ini akuntansi tradisional (konvensional) dengan dasar akuntansi keuangan cenderung mengabaikan faktorfaktor sosial dan lingkungan dalam proses operasional keuangannya dan proses pelaporan keuangan kepada para pemakai. Sehingga dalam laporan keuangan entitas perusahaan, tidak ada akun yang terkait dengan aset sumber daya alam dan lingkungan [16].

Ketiadaan informasi akuntansi sosial dan lingkungan, serta salah kaprah dalam perlakuan akuntansi dan pelaporan terhadap informasi CSR telah menyebabkan informasi keuangan yang tersaji dalam laporan keuangan dinilai kurang relevan dan reliable. Informasi akuntansi dikritik telah menyesatkan pihak-pihak terkait dalam penilaian dan pengambilan keputusan investasi, operasional, dan pembiayaan, serta menyesatkan dalam perencanaan, pengendalian, dan pelaksanaan operasi bisnis yang terkait dengan isu-isu sosial dan lingkungan, serta keberlanjutan perusahaan.

\section{Kedudukan Akuntansi Lingkungan dalam Keberlanjutan (Sustainability) Perusahaan}

Beberapa negara Eropa, Amerika Serikat serta Jepang, akuntansi lingkungan sudah diterapkan. Misalnya di Jepang, laporan akuntansi lingkungan sudah memiliki standar sehingga selain menghasilkan laporan internal, perusahaan juga diwajibkan menghasilkan laporan eksternal yang terpisah dari laporan lainnya. Khususnya di Indonesia tingkat penerapan akuntansi lingkungan pada perusahaan belum maksimal, dimana secara rata-rata berada pada level 69,80\% dan termasuk dalam kategori cukup [9]. Hal ini disebabkan karena banyaknya perusahaan yang telah menerapkan akuntansi lingkungan belum membuat laporan 
lingkungan secara terpisah masih menggabungkan dengan laporan tahunan (annual report). Hampir semua laporan menggunakan indeks GRI (Global Reporting Initiative). GRI adalah suatu lembaga internasional yang menerbitkan pedoman pelaporan berkelanjutan atau pelaporan corporate social responsibility (CSR).

Konsep keberlanjutan adalah pembangunan ekonomi dan bisnis untuk kepentingan pertumbuhan ekonomi dan laba yang dilakukan dengan metode yang memasukkan nilai tanggung jawab secara sosial dan lingkungan. Integrasi kepentingan ekonomi atas tanggung jawab tersebut direlasikan dengan menyejahterakan masyarakat dan memelihara kelestarian lingkungan secara adil dan berkelanjutan.

Upaya mewujudkan implementasi pembangunan berkelanjutan, pemerintah mulai mendesak perlunya pelaku bisnis dan perusahaan untuk peduli dan berkomitmen dalam mengimplementasikan tanggung jawab sosial dan lingkungan secara berkesinambungan. Pelaku bisnis merespon permintaan tersebut dengan mengadopsi dan mengembangkan praktik tanggung jawab sosial dan lingkungan yang relevan dengan kebutuhan dan strategi bisnisnya. Bahkan tanggung jawab sosial dan lingkungan dirancang menjadi strategi bisnis yang bersifat sukarela untuk membantu keberlanjutan ekonomi dan bisnis, pertumbuhan laba, dan keberlanjutan perusahaan dalam jangka panjang [17].

Menurut Elkington (1998) merumuskan konsep tiga pilar dasar dari bisnis yaitu pilar pertama, bumi atau lingkungan (planet), kedua, masyarakat pemangku kepentingan (people), dan ketiga, laba atau keuntungan (profit). Ketiga pilar ini sering disebut sebagai 3P. Adanya pengintegrasian dan pengelolaan secara baik atas ketiga pilar dasar bisnis tersebut, maka secara tidak langsung akan mendukung keberhasilan dan keberlanjutan bisnis dan pertumbuhan laba. Integrasi dan tata kelola konsep 3P (People, Planet, dan Profit) sangat penting dilakukan secara baik dalam perusahaan, hal ini untuk menekankan kepedulian dan komitmen melaksanakan tanggung jawab sosial dan lingkungan yang bersifat wajib maupun bersifat sukarela secara berkelanjutan. Tanggung jawab sosial dan lingkungan atau CSR memiliki dua dimensi tanggung jawab tersebut [18].

Implementasi tanggung sosial dan lingkungan perusahaan memiliki dampak positif terhadap kinerja periodik dan nilai perusahaan dengan bukti dari kepedulian perusahaan dalam pengimplementasian tanggung jawab sosial dan lingkungan secara berkesinambungan dimana juga berpengaruh pada peningkatan kinerja dan nilai dari suatu entitas serta keberlanjutan perusahaan [5], [15]. Selain itu juga, banyak perusahaan yang memperluas program tanggung jawab sosial dan lingkungannya dengan konsekuensi menyerap sumber 
daya ekonomi dan non-ekonomi yang besar. Tanggung jawab sosial dan lingkungan nampaknya telah dijadikan kebutuhan pokok perusahaan, yaitu sebagai investasi strategis untuk memperkuat pilar dasar bisnis dan mengembangkan bisnis dan menaikkan laba perusahaan secara berkelanjutan dalam jangka panjang [5].

Ada tiga faktor yang menjadi alasan mengapa perusahaan melakukan pengelolaan lingkungan yaitu: a) adanya kesadaran untuk meningkatkan kinerja keuangan. Hal ini sejalan dengan dukungan dari penelitian Birkin dan Woodward (1997) bahwa saat ini kemampuan perusahaan untuk meraih kinerja lingkungan lebih penting daripada meraih kinerja ekonomi atau kinerja keuangan yang baik, b) adanya tekanan eksternal dari berbagai pihak (stakeholder). Alasan kedua ini didukung oleh konteks dari stakeholder theory yang menyatakan bahwa untuk keberlanjutan operasional suatu perusahaan membutuhkan dukungan dari stakeholder [19]. Dalam hal ini yang paling pokok adalah pemerintah yang memiliki kepentingan atas kepatuhan perusahaan terhadap regulasi lingkungan dengan tujuan melindungi masyarakat. c) adanya motivasi untuk meningkatkan kinerja keuangan perusahaan [20]. Sejalan dengan penelitian De Beer dan Friend (2006) bahwa aspek lingkungan perusahaan akan menjadi fokus kepedulian ketika perusahaan meyakini akan memberikan peningkatan pada kinerja keuangannya [21]. Didukung oleh Iwata dan Okada (2011) menyatakan bahwa ketika kinerja lingkungan suatu perusahaan berpengaruh positif terhadap kinerja keuangan, maka secara otomatis akan dampak pada insentif perusahaan. Dalam artian bahwa tujuan akhir dari perusahaan adalah perbaikan kinerja keuangan juga akan naik dengan baiknya kinerja lingkungan perusahaan [22].

Menurut Bossard (2011) ada dua bentuk manfaat akuntansi lingkungan yaitu: a) urgensi operasional bagi perusahaan mencakup dalam mendeteksi biaya lingkungan, pengelolaan biaya dalam akun yang terpisah, membantu mendeteksi biaya lingkungan, mengelola biaya lingkungan dalam akun yang terpisah, Memberikan informasi tentang cara mengurangi biaya dan meningkatkan penjualan, memberikan informasi sumber daya dan polusi terkait, membantu mencegah polusi, menciptakan kelestarian lingkungan, dan mendukung sistem manajemen lingkungan. b) manfaat pemasaran dan prospek pihak eksternal misalnya, mengurangi risiko, memfasilitasi kepatuhan terhadap peraturan lingkungan dan citra positif, dalam meningkatkan laba. Secara garis besar, akuntansi lingkungan sebagai tools perusahaan dalam rangka pencegahan polusi dalam transformasi perusahaan yang sustainable [23]. 


\section{KESIMPULAN}

Berdasarkan uraian sebelumnya, maka kesimpulan dalam artikel ini bahwa hakikatnya perusahaan yang bertujuan untuk meraih laba yang menuntut perusahaan agar lebih bertanggung jawab, seharusnya tidak mengorbankan masyarakat sekitar dan lingkungannya. Hakikat dari tanggung jawab sosial perusahaan adalah keberlanjutan suatu kegiatan operasional suatu perusahaan dengan berfokus pada kepedulian terhadap masyarakat dan lingkungan dalam rangka menjalin sinergitas antara bisnis, masyarakat dan lingkungan. Komitmen tersebut bersifat sukarela dan sejalan dengan visi dan keinginan perusahaan dalam menciptakan lingkungan yang saling melengkapi, kondusif, dan berkelanjutan.

Kritikan dalam hal penilaian dan pengambilan keputusan ekonomi dan bisnis atas informasi akuntansi yang selama ini dianggap telah menyesatkan para pemakainya yang terkait dengan isu sosial dan lingkungan. Pengabaian tersebut telah mendorong perusahaan dan pihak-pihak terkait untuk semakin tidak peduli dan berperilaku serakah terhadap sumber daya alam dan lingkungan, serta masyarakat sekitar. Oleh karena itu, menyebabkan terjadinya eskalasi kerusakan lingkungan, serta krisis ekologi dan krisis sosial.

Hakikatnya tanggung jawab perusahaan tidak hanya berkaitan dengan aspek-aspek bisnis dan pemangku kepentingan yang memiliki relasi ekonomi atau bisnis dengan perusahaan. Selain itu juga, bertanggung jawab kepada masyarakat dan lingkungan yang berada di sekitar perusahaan atau yang merasakan dampak eksternalitas dari aktivitas operasi perusahaan. Sehingga dalam melaksanakan tiga pilar dasar 3P (People, Planet, dan Profit) secara berkesinambungan, maka fundamental bisnis dan ekonomi akan semakin kuat. Perusahaan juga akan tumbuh dan berkembang secara berkelanjutan.

\section{DAFTAR PUSTAKA}

[1] J. E. Heard and W. J. Bolce, "The Political Significant of Corporate Social Reporting in The United States of America Accounting," J. Accounting, Organ. Soc., vol. 6, no. 3, pp. 247-254, 1972.

[2] C. Reverte, "Determinants of Corporate Social Responsibility Disclosure Rating by Spanish Listed Firms,” J. Bus. Ethics, vol. 88, pp. 351-366, 2008.

[3] B. Rudito and M. Famiola, Etika Bisnis dan Tanggung Jawab sosial Perusahaan di Indonesia. Jakarta: Rekayasa Sains, 2007.

[4] T. Borglund and E. Al., CSR Corporate Social Responsibility En Guide Till Foretagets Ansvar. Stockholm: Sanoma Utbildning, 2012.

[5] A. Lako, Green Economy: Menghijaukan Ekonomi, Bisnis, dan Akuntansi. Jakarta: 
PT Erlangga, 2015.

[6] F. Bell and G. Lehman, "Recent Trends in Environmental Accounting: How Green Are Your Account," in Accounting Forum, 1999.

[7] Y. Aniela, "Peran Akuntansi Lingkungan dalam Meningkatkan Kinerja Lingkungan dan Kinerja Keuangan Perusahaan," Berk. Ilm. Mhs. Akunt., vol. 1, no. 1, pp. 15-19, 2012.

[8] M. Bennett and P. James, Sustainable Measures: Evaluation and Reporting of Environmental and Social Performance. Sheffield: Greenleaf Publishing, 1999.

[9] D. I. Burhany, "Pengaruh Implementasi Akuntansi Lingkungan terhadap Kinerja Lingkungan dan Pengungkapan Informasi Lingkungan serta Dampaknya Terhadap Kinerja Keuangan Perusahaan," Indones. J. Econ. Bus., vol. 1, no. 2, pp. 257-270, 2011.

[10] J.-F. Henri and M. Journeault, "Eco-Control: The Influence of Management Control Systems on Environmental And Economic Performance," Accounting, Organ. Soc., vol. 35, no. 1, pp. 63-80, 2010.

[11] I. Ghozali and A. Chariri, Teori Akuntansi. Semarang: Badan Penerbit Undip, 2007.

[12] P. Shrivastava and S. Hart, "Creating Sustainable Corporations," Bus. Strateg. Environ., vol. 4, no. 3, pp. 154-165, 1995.

[13] A. McWilliams and D. Siegel, "Corporate Social Responsibility and Financial Performance: Correlation Or Misspecification," Strateg. Manag. J., vol. 21, no. 5, pp. 603-9, 2000.

[14] D. Grinnell and H. Hunt, "Development of an Integrated Course in Accounting: A Focus on Environmental Issues," Issues Account. Educ., vol. 15, no. 1, 2000.

[15] A. Gore, The Future: Six Drivers of Global Change. New York: Random House, 2013.

[16] A. Lako, "Transformasi Menuju Akuntansi Hijau - Desain Konsep dan Praktik," in Simposium Nasional Akuntansi (SNA) ke-19, 2016.

[17] S. Benn and D. Bolton, Key Concepts in Corporate Social Responsibility. London: SAGE Publication. Ltd., 2011.

[18] J. Elkington, Cannibals With Forks: The Triple Bottom Line of 21st Century Business. United Kingdom: Capstone, 1997.

[19] F. Birkin and D. Woodward, "Accounting for the Sustainable Corporation," Environ. Manag. Heal., vol. 8, no. 2, 1997.

[20] R. Gray, R. Kouhy, and S. Lavers, "Corporate Social and Environmental Reporting: A Review of Literature and a Longitudinal Study of UK Disclosure," Accounting, Audit. Account. J., vol. 8, no. 2, pp. 47-76, 1995. 
[21] P. De Beer and F. Friend, "Environmental Accounting: A Management Tool for Enhancing Corporate Environmental and Economic Performance," Ecol. Econ., vol. 58, pp. 548-560, 2006.

[22] H. Iwata and K. Okada, "How Does Environmental Performance Affect Financial Performance? Evidence from Japanese Manufacturing Firms.," Japan, 2010. [Online]. Available: https://mpra.ub.unimuenchen.de/27721/1/MPRA_paper_27721.pdf.

[23] R. E. Bosshard, "Environmental Accounting: A Case Study of its Application to a Small Business in Atlantic Canada,” Dalhousie University Halifax, 2011. 